\title{
Glutaric Aciduria Type II: Evidence for a Defect Related to the Electron Transfer Flavoprotein or Its Dehydrogenase
}

\author{
E. CHRISTENSEN, ${ }^{(17)}$ S. KøLVRAA, AND N. GREGERSEN
}

Section of Clinical Genetics, Department of Pediatrics and Department of Obstetrics and Gynaecology, Rigshospitalet, University of Copenhagen, Blegdamsvej 9, 2100 Copenhagen, Denmark [E. C.], Institute of Human Genetics, University of Aarhus, Aarhus, Denmark [S. K.], and Research Laboratory for Metabolic Disorders, University Department of Clinical Chemistry, University of Aarhus, Aarhus, Denmark [N. G.]

\section{Summary}

Incubation of intact fibroblasts from a patient with glutaric aciduria type II with $\left[2-{ }^{14} \mathrm{C}\right]$ riboflavin showed normal synthesis of flavin mononucleotide and flavin adenine dinucleotide. This is taken as evidence for normal transport of riboflavin into the cells and normal activity of riboflavin kinase (EC 2.7.1.26) and flavin mononucleotide adenylyltransferase (EC 2.7.7.2).

The ability of intact fibroblasts to oxidize $1-{ }^{14} \mathrm{C}$-fatty acids and $\left[6-{ }^{14} \mathrm{C}\right]$ lysine is impaired in the patient which together with the urinary excretion pattern of organic acids indicates a defective dehydrogenation of fatty acid acyl-CoAs and glutaryl-CoA. However, dehydrogenation of $\left(C_{6}-C_{10}\right)$ fatty acid acyl-CoA derivatives and glutaryl-CoA was normal when the dehydrogenases were measured in fibroblast homogenate with artificial electron acceptors. In vivo, these dehydrogenases transfer their electrons to $\mathrm{CoQ}_{10}$ in the main electron transport chain via electron transfer flavoprotein and electron transfer flavoprotein dehydrogenase. Glutaric aciduria type II fibroblasts showed very diminished activity when the glutaryl-CoA dehydrogenase activity was measured without artificial electron acceptor but with intact endogenous electron transport system. As the NADH and succinate oxidation seems normal in glutaric aciduria type II patients, this is strong evidence for a defect in either the electron transfer flavoprotein or the electron transfer flavoprotein dehydrogenase.

\section{Abbreviations}

DCPIP, 2,6-dichlorphenolindophenol

DPBS, Dulbecco's phosphate-buffered saline

EA, electron acceptor

ETF, electron transfer flavoprotein

ETF-DH, electron transfer flavoprotein dehydrogenase

ETC, electron transport chain

ETS, electron transport system (i.e. ETF, ETF-DH, and the ETC from $\mathrm{CoQ}_{10}$ to $\mathrm{O}_{2}$ )

GA I, glutaric aciduria type I

GA II, glutaric aciduria type II

GADH, general acyl-CoA dehydrogenase

GDH, glutaryl-CoA dehydrogenase

$\mathrm{MB}$, methylene blue

The neonatal form of GA II is a serious metabolic disorder with symptoms starting within the first days of life $(3,7,8,11$, 14). The infants with this disorder become lethargic and hypotonic, they develop severe hypoglycemia and acidosis. Death usually occurs a few days after onset of symptoms. Biochemically, the disease is characterized by the urinary excretion of a number of organic acids that all seem to be derived from substrates to a group of FAD containing acyl-CoA dehydrogenases $(8,11)$. Some of the patients have also been noted to have high plasma sarcosine and to excrete elevated amounts of sarcosine in the urine $(7,8)$. This abnormal metabolic pattern is explained by deficiency of the enzyme systems of the fatty acid acyl-CoA dehydrogenation, the acyl-COA dehydrogenation involved in the degradation of the three branched chain amino acids, the glutaryl-CoA dehydrogenation and the sarcosine dehydrogenation (8).

A normal synthesis of FAD by kidney homogenate from one patient indicated the presence of normal amounts of this coenzyme for all the involved dehydrogenases (7).

Fibroblasts from patients with GA II have shown diminished ability to oxidize ${ }^{14} \mathrm{C}$-labeled substrates for the flavoprotein acylCoA dehydrogenases $(11,12)$.

A defect in ETF common for all the defective dehydrogenases has been suggested by several investigators including ourselves $(7,8)$. Recently, the ETF has been measured in fibroblasts from the first reported patient with glutaric aciduria type II and found to be normal or increased (12). The present work describes the investigations performed on cultured skin fibroblasts from our patient with GA II to further characterize the defect. Normal uptake of $\left[2-{ }^{14} \mathrm{C}\right]$ riboflavin and normal synthesis of FMN and FAD was found. The oxidation of $\left(\mathrm{C}_{6}-\mathrm{C}_{16}\right) 1-{ }^{14} \mathrm{C}$-fatty acids and $\left[6-{ }^{14} \mathrm{C}\right]$ lysine to ${ }^{14} \mathrm{CO}_{2}$ was significantly decreased in intact fibroblasts from the patient. The glutaryl-CoA and medium chain $\left(\mathrm{C}_{6}-\mathrm{C}_{10}\right)$ acyl-CoA dehydrogenases in fibroblast homogenate were normal using artificial electron acceptors. However, glutaryl-CoA dehydrogenase activity was very much decreased with intact ETC. These results are consistent with the proposed defect of ETF or ETF-DH.

\section{MATERIALS AND METHODS}

The chemicals used were obtained from the following sources: $\left[1,5-{ }^{14} \mathrm{C}\right]$ glutaric acid and DL- $\left[6-{ }^{-14} \mathrm{C}\right]$ lysine from CIS (France, Belgium, and Italy); $1-{ }^{14} \mathrm{C}$-labeled even-numbered fatty acids from New England Nuclear; $\left[2-{ }^{14} \mathrm{C}\right]$ riboflavin from Amersham, England; riboflavin, FMN, FAD, and $\mathrm{COA}$ from Boehringer, Germany; DCPIP, MB, and trichloroacetic acid from Merck, Germany; methylbenzethonium hydroxide (Hyamin) from Sigma; L-lysine $\mathrm{HCl}$ from Calbiochem, Switzerland; fetal Calf serum from Gibco, Scotland; medium 199, DPBS, and Hanks balanced salts from Flow Laboratories, Scotiand; and Insta-Fluor and Insta-Gel from Packard Instrument Company.

Assays for glutaryl-CoA dehydrogenase. The first method to 
determine GDH activity used $\mathrm{MB}$ as EA as earlier described (1, 2; Fig. 1). The second method measured GDH activity without exogenous EA and was dependent on the intact endogenous ETS. Different homogenizing procedures were investigated with this method. The procedure that gave the highest activity in normal fibroblasts was chosen as the method for investigating the activity in fibroblasts from GA II patients. The first method determined GDH activity alone whereas the second method also measured the endogenous ETS (see Fig. 2). The second method was thus able to detect defects in GDH as well as in ETS. All assays were performed in duplicate. The values shown in Tables 5,6 , and 7 were the results of three or more separate determinations.

Estimation of the oxidation rate for $\left[6-^{14} \mathrm{C}\right]$ lysine. Oxidation of $\left[6{ }^{14} \mathrm{C}\right]$ lysine was performed by a method modified from Dancis et al. (4). Fibroblasts were grown to confluence in 25$\mathrm{cm}^{2}$ flasks. The cells were washed three times with $5 \mathrm{ml}$ DPBS with the cells still attached to the bottom. $0.5 \mathrm{ml}$ DPBS containing $0.33 \mathrm{mmol} /$ liter $\left[6-{ }^{14} \mathrm{C}\right]$ lysine (specific activity, $2.5 \mathrm{mCi}$ / mol) was added and the flasks were incubated at $37^{\circ} \mathrm{C}$ for $4 \mathrm{~h}$. Scintillation flasks containing a piece of pleated filter paper moistened with $100 \mu \mathrm{l}$ Hyamin were attached to the culture flasks by means of a piece of rubber tubing during incubation. The incubation was stopped by injection of $100 \mu \mathrm{l}$ of $30 \%$ trichloroacetic acid into the culture flasks through the rubber tubing. The released ${ }^{14} \mathrm{CO}_{2}$ was collected, while shaking the flasks gently at $37^{\circ} \mathrm{C}$ for a further $60 \mathrm{~min} .10 \mathrm{ml}$ Insta-Fluor was added to each scintillation flask and the amount of ${ }^{14} \mathrm{CO}_{2}$ was counted in a Betaszint scintillation counter. The cell monolayer was dissolved in a strong base and aliquots were used for protein determination using the Lowry method (10).

Oxidation of $1-{ }^{14} C$-fatty acids $\left(C_{6}-C_{16}\right)$. The determination of the rate of fatty acid oxidation was performed as earlier described (9).

Dehydrogenation of medium chain acyl-CoA $\left(C_{6}-C_{10}\right)$. Measurement of acyl-CoA dehydrogenases in fibroblast homogenate

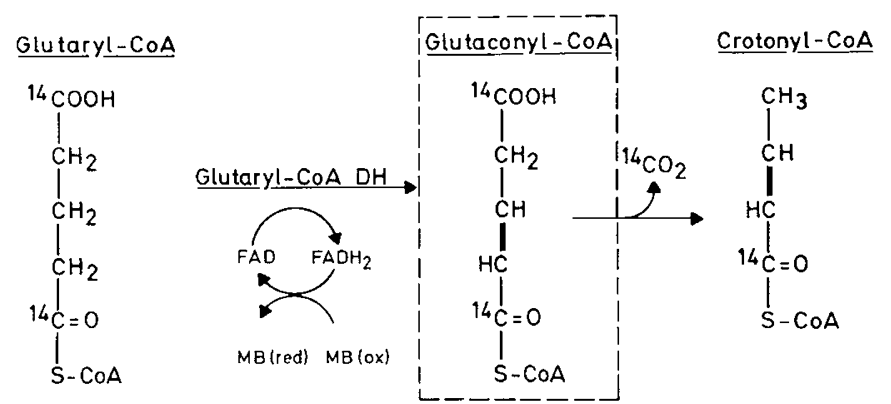

Fig. 1. Glutaryl-CoA dehydrogenation with $\mathrm{MB}$ as exogenous electron acceptor.

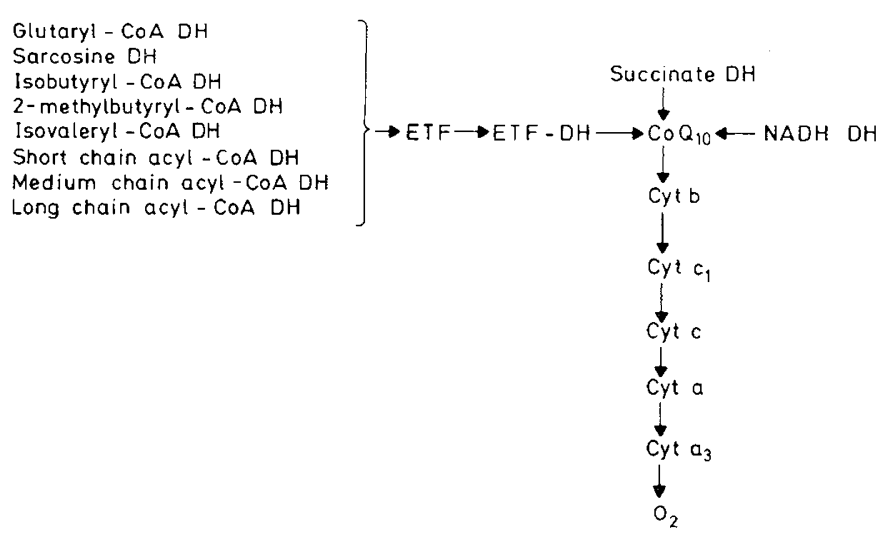

Fig. 2. The electron transport to the respiratory chain for the ETFand ETF-DH-dependent dehydrogenases. was performed by selected ion monitoring gas chromatography/ mass spectrometry of the $3-\mathrm{OH}$-acids formed from the reaction products after enzymatic hydration of the unsaturated acyl-CoA derivatives by purified crotonase and hydrolysis of the thioesters. The method has been described in detail elsewhere (9).

FAD and FMN synthesis in fibroblasts: Method I. Fibroblasts were grown to confluence in $75-\mathrm{cm}^{2}$ Falcon Flasks in medium 199 containing $15 \%$ fetal calf serum. For measuring riboflavin uptake and conversion, the growth medium was replaced by medium 199 without fetal calf serum but containing $20 \mu \mathrm{mol} /$ liter $\left[2-{ }^{14} \mathrm{C}\right]$ riboflavin (specific activity, $60 \mathrm{mCi} / \mathrm{mmol}$ ). After incubation for $24 \mathrm{~h}$ at $37^{\circ} \mathrm{C}$, the incubation was stopped and cells washed three times with $10 \mathrm{ml}$ DPBS. The cells were then harvested with trypsin-EDTA and further washed twice with DPBS. $3 \mathrm{ml}$ of a solution containing $0.033 \mathrm{mg} / \mathrm{ml}$ riboflavin, FMN, and FAD were added. The cells were homogenized in a Potter-Elvehjem homogenizer, subjected to three cycles of freezing and thawing, and finally sonified $3 \times 10 \mathrm{sec}$ on a MSE 150W Sonifier. An aliquot was used for protein determination. $6 \mathrm{ml}$ methanol was added to the rest of the homogenate and proteins were allowed to precipitate at $4^{\circ} \mathrm{C}$ for $18 \mathrm{~h}$ in the dark. The precipitate was pelleted by centrifugation for $30 \mathrm{~min}$ at $3000 \times$ g. $5 \mathrm{ml}$ of the supernatant was evaporated to dryness in a stream of nitrogen. The residue was redissolved in $2 \mathrm{ml}$ distilled water and applied to a DEAE-Sephadex A-25 column. Riboflavin and its derivatives were then eluted by $1 \%$ ammonium sulfate as described by Fazekas and Sandor (6).

Fractions containing the individual flavins were pooled and a fraction was mixed with Insta-gel and counted in a liquid scintillation counter. The intracellular concentrations of labeled riboflavin, FMN, and FAD were expressed as $\mathrm{cpm} / \mathrm{mg}$ protein.

Method II. Fibroblasts were grown to confluence in $75-\mathrm{cm}^{2}$ Falcon flasks in medium 199 containing $15 \%$ FCS. The medium was then replaced by $0.040 \mu \mathrm{mol} /$ liter $\left[2-{ }^{4} \mathrm{C}\right.$ ]riboflavin (specific activity, $60 \mathrm{mCi} / \mathrm{mmol}$ ) dissolved in Hanks' balanced salt solution. The cells were incubated for $4 \mathrm{~h}$ at $37^{\circ} \mathrm{C}$. The measurement of the intracellular concentration of labeled riboflavin, FMN, and FAD was then performed as for method I.

\section{RESULTS}

The ability of the mutant fibroblasts to take up $\left[2-{ }^{14} \mathrm{C}\right]$ riboflavin and convert it to labeled FMN and FAD was similar to that of fibroblasts from normal individuals (Table 1). This was the case both at a saturated $\left[2-{ }^{14} \mathrm{C}\right]$ riboflavin concentration, where an increase in $\left[2-{ }^{14} \mathrm{C}\right]$ riboflavin did not result in a further increase in FAD synthesis and at a low $\left[2-{ }^{14} \mathrm{C}\right]$ riboflavin concentration with no saturation of FAD synthesis.

Table 2 shows the oxidation rates for $1-{ }^{14} \mathrm{C}$-labeled evennumbered fatty acids $\left(\mathrm{C}_{6}-\mathrm{C}_{16}\right)$ by intact fibroblasts from normal individuals and the patient. A significant decrease in the ability to oxidize $1-{ }^{14} \mathrm{C}$-fatty acids is seen for the mutant fibroblasts.

The oxidation rates of DL- $\left[6-{ }^{14} \mathrm{C}\right] l y s i n e$ by different mutant cell lines is compared to cell lines from normal individuals in Table 3. The lowest oxidation rate is seen in two patients with hyperlysinemia. The oxidation rate in the patient with GA II is

Table 1. Incorporation of $\left[2-{ }^{14} \mathrm{C}\right]$ riboflavin into FMN and FAD by intact fibroblasts from the patient and from two normal individuals*

\begin{tabular}{|c|c|c|c|c|}
\hline & \multicolumn{2}{|c|}{$\begin{array}{l}\text { 24-h incubation with } 20 \\
\mu \mathrm{mol} / \mathrm{liter}\left[2-{ }^{14} \mathrm{C}\right] \text { ribo- } \\
\text { flavin }(\mathrm{cpm} / \mathrm{mg} \text { protein })\end{array}$} & \multicolumn{2}{|c|}{$\begin{array}{c}\text { 4-h incubation with } \\
0.040 \mu \mathrm{mol} / \mathrm{liter}\left[2-{ }^{14} \mathrm{C}\right] \\
\text { riboflavin }(\mathrm{cpm} / \mathrm{mg} \text { pro } \\
\text { tein) }\end{array}$} \\
\hline & FMN & FAD & FMN & FAD \\
\hline Control 1 & 695 & 7521 & 0 & 1007 \\
\hline Control 2 & 578 & 5316 & 0 & 1210 \\
\hline Patient & 475 & 4906 & 0 & 911 \\
\hline
\end{tabular}

* Each value is the mean of three separate determinations. 
Table 2. Oxidation of $1 \mathrm{I}^{14} \mathrm{C}$-fatty acids by intact fibroblasts expressed as $\mathrm{pmol} / \mathrm{min} / \mathrm{mg}$ protein*

\begin{tabular}{lcccccc}
\hline & Hexanoic acid & Octanoic acid & Decanoic acid & Lauric acid & Myristic acid & Palmitic acid \\
\hline $\begin{array}{l}\text { Mean } \pm \text { SD and range in con- } \\
\text { trols }\end{array}$ & $1.26 \pm 0.29$ & $0.60 \pm 0.20$ & $1.81 \pm 0.50$ & $1.62 \pm 0.45$ & $1.23 \pm 0.27$ & $4.78 \pm 1.0$ \\
& $(n=6)$ & $(n=6)$ & $(n=6)$ & $(n=5)$ & $(n=5)$ & $(n=6)$ \\
& $(1.03-1.75)$ & $(0.38-0.83)$ & $(1.20-1.24)$ & $(0.97-2.07)$ & $(1.02-1.68)$ & $(3.61-6.81)$ \\
Activity in the patient with glu- & 0.34 & 0.07 & 0.26 & 0.16 & 0.23 & 0.90 \\
$\quad$ taric aciduria type II & $<0.025$ & $<0.025$ & $<0.025$ & $<0.025$ & $<0.025$ & $<0.01$ \\
$P \dagger$ & & &
\end{tabular}

* For the patient, each value is the mean of a duplicate determination.

$\dagger$ Student's $t$ test (one-tailed) was used to compare activities in cells from the patient with activity in control cells.

Table 3. Oxidation of $\left[6^{-14} \mathrm{C}\right] l y$ sine by fibroblasts from patients with glutaric aciduria types I and II and from patients with hyperlysinemia with and without saccharopinuria and from normal individuals*

\begin{tabular}{|c|c|c|}
\hline Patient & $\begin{array}{c}{ }^{14} \mathrm{CO}_{2} \text { evolved } \\
(\mathrm{pmol} / \mathrm{min} / \mathrm{mg} \text { protein })\end{array}$ & $\%$ of control \\
\hline Controlst & $\begin{array}{l}0.45 \\
(0.39-0.52)\end{array}$ & 100 \\
\hline $\begin{array}{l}\text { Glutaric aciduria type } \\
\text { I }\end{array}$ & 0.21 & 47 \\
\hline $\begin{array}{l}\text { Glutaric aciduria type } \\
\text { II }\end{array}$ & 0.20 & 44 \\
\hline $\begin{array}{l}\text { Patient with hyperlysi- } \\
\text { nemia }\end{array}$ & 0.08 & 18 \\
\hline $\begin{array}{l}\text { Patient with hyperlysi- } \\
\text { nemia and sacchar- } \\
\text { opinuria }\end{array}$ & 0.04 & 9 \\
\hline
\end{tabular}

* For each individual, the value is the mean of two determinations.

t The activity is the mean of the activity found in three normal individuals. The range is in parentheses.

about half the normal rate and similar to the rate in patients with GA I.

Medium chain acyl-CoA dehydrogenase activity estimated by direct dehydrogenation of $\left(\mathrm{C}_{6}-\mathrm{C}_{10}\right)$ acyl-CoA by fibroblast homogenate is shown in Table 4. Normal activity was found in the homogenates of GA II fibroblasts. Glutamate dehydrogenase was determined as a reference mitochondrial enzyme. The normal dehydrogenation of $\left(\mathrm{C}_{6}-\mathrm{C}_{10}\right)$ acyl-CoAs by fibroblast lysate from GA II patients is in contrast to the very decreased oxidation by intact cells of $\left(C_{6}-C_{16}\right)$ fatty acids as seen in Table 2 and indicates that the dehydrogenases are functioning normally.

In order to investigate the influence of the homogenizing procedure, GDH activities have been measured in normal fibroblasts both with $\mathrm{MB}$ and without any exogenous EA, but with intact endogenous ETS after five different homogenizing procedures as shown in Table 5. The highest activity with MB as EA was obtained with procedure I. This was comparable to the previously reported procedure (2). The measured activity with $\mathrm{MB}$ as EA decreased when part of the procedure was omitted, and less than $10 \%$ of normal activity when only one stroke of a Potter-Elvehjem homogenizer was used. The GDH activity with no exogenous EA but with intact endogenous ETS on the contrary increased with less vigorous homogenizing procedure. Maximum activity was obtained with one freeze-thaw cycle after Potter-Elvehjem homogenizing. Without the freeze-thaw cycle, the activity decreased as did the activity with MB as EA. Centrifugation of the fibroblast homogenate for $1 \mathrm{hr}$ at $50,000 \times \mathrm{g}$ completely abolished the glutaryl-CoA dehydrogenase activity without exogenous EA as did the addition of $0.1 \%$ Triton $\mathrm{X}$ 100 , while the MB-dependent activity was unchanged. In agreement with the results from Table 5, homogenizing procedure IV was used for the determination of GDH activity with endogenous $\mathrm{EA}$ (i.e. intact ETC).

In Table 6 are shown the GDH activities in normal fibroblasts measured with homogenizing procedure 4 from Table 5 after the addition of compounds known to inhibit the ETC. GDH activity is inhibited by both $\mathrm{KCN}$ and antimycin $\mathrm{A}$. The activities with only endogenous EA are inhibited most, indicating that the GDH activities with no exogenous EA are dependent on an intact ETC for activity.

The GDH activities in different fibroblast cell lines are shown in Table 7 both with endogenous EA and with MB as EA. The activities in normal individuals with $\mathrm{MB}$ as EA are lower than previously reported (2). This is caused by the suboptimal homogenizing procedure for this method.

GA I heterozygotes showed the same ratio as normal homozygotes between the activity measured with endogenous EA and the activity with MB as EA (see last column in Table 7). GA I homozygotes have no activity with either endogenous ETS or $\mathrm{MB}$ as EA whereas GA II homozygotes have normal activity measured with $\mathrm{MB}$ as EA but very low activity with endogenous EA (i.e. with intact ETC). In contrast to GA I heterozygotes with half-normal activity with both assay methods, GA II heterozygotes cannot be distinguished from normal homozygotes by these two methods.

\section{DISCUSSION}

All cases of neontal GA II described have been characterized by the urinary excretion of a great number of organic acids that all seem to be derived from substrates to a group of FADcontaining acyl-CoA dehydrogenases (8). Besides FAD, these dehydrogenases have in common a transfer of electrons through ETF and ETF-DH to CoQ 10 in the ETC (see Fig. 2). The normal activities of the fatty acyl-CoA dehydrogenases and of GDH measured on fibroblast homogenate with artificial electron acceptors strongly indicate that the dehydrogenases themselves are functioning normally in GA II.

A defect in a common factor for all of the involved dehydrogenases has been considered. One such factor is FAD, the common prosthetic group for all the apparently involved enzymes. A decreased synthesis of FAD as already suggested by Przyrembel et al. (11) could be the cause of the defective function of the dehydrogenases in vivo. Goodman et al. (7) investigated the ability of an autopsy kidney specimen from one of his patients with GA II to synthesize FMN and FAD from $\left[2-{ }^{14} \mathrm{C}\right.$ ]riboflavin and found no difference between autopsy kidney from the patient and three controls. As has been reported that whole liver homogenate only has slight net synthesis of FMN and FAD due to degradation by factors contained in the mitochondria (5), we decided to reinvestigate the FMN and FAD production from [2${ }^{14} \mathrm{C}$ ]riboflavin in our patient using whole living fibroblasts as the tissue for investigation.

Two different methods were used: one using 24-h incubation in normal medium and a high $\left[2-{ }^{14} \mathrm{C}\right]$ riboflavin concentration and one using 4-h incubation in a salt solution containing glucose but without unlabeled riboflavin and a rather low $\left[2-{ }^{14} \mathrm{C}\right]$ riboflavin concentration not saturating the FMN- and FAD-synthesizing system. The latter system should be able to detect a defective uptake of riboflavin by the mutant cells. Both methods showed normal FAD synthesis by the mutant cells, thus confirming the results by Goodman et al. (7) that FAD synthesis is normal in patients with GA II.

ETF and ETF-DH are essential factors for the FAD-containing 
Table 4. Dehydrogenase activity in fibroblast homogenate expressed as $n m o l / h / m g$ protein*

\begin{tabular}{|c|c|c|c|c|}
\hline & \multicolumn{4}{|c|}{ Substrate } \\
\hline & Hexanoyl-CoA & Octanoyl-CoA & Decanoyl-CoA & Glutamate $\dagger$ \\
\hline $\begin{array}{l}\text { Mean } \pm \mathrm{SD} \text { and range in } \\
\text { controls }\end{array}$ & $\begin{array}{c}18.2 \pm 6.4 \\
(n=5) \\
(11.0-24.4)\end{array}$ & $\begin{array}{c}30.0 \pm 12.1 \\
(n=5) \\
(15.0-42.1)\end{array}$ & $\begin{array}{c}22.3 \pm 5.8 \\
(n=5) \\
(12.9-28.3)\end{array}$ & $\begin{array}{c}26.2 \pm 4.8 \\
(n=4) \\
(19.3-29.9)\end{array}$ \\
\hline $\begin{array}{l}\text { Glutaric aciduria type II } \\
\text { patient }\end{array}$ & 22.6 & 27.7 & 26.2 & 23.0 \\
\hline
\end{tabular}

* For the patient, each value is the mean of a duplicate determination.

$\dagger \mathrm{nmol} / \mathrm{min} / \mathrm{mg}$ protein.

Table 5. The influence of the homogenizing procedure on the glutaryl-CoA dehydrogenase activity both with MB and with endogenous electron acceptors

\begin{tabular}{|c|c|c|c|}
\hline \multirow[b]{2}{*}{ Homogenizing procedure } & \multicolumn{2}{|c|}{$\begin{array}{l}\text { Glutaryl-CoA dehydrogenase activity } \\
\qquad(\mu \mathrm{mol} / \mathrm{h} / \mathrm{g} \text { protein })\end{array}$} & \multirow{2}{*}{$\frac{100 \times \mathrm{B}}{\mathrm{A}}$} \\
\hline & With MB as EA (A) & With endogenous EA (B) & \\
\hline $\begin{array}{l}\text { I. Potter-Elvehjem homogenizing } 1 \text { freeze- } \\
\text { thaw cycle, } 0.1 \% \text { Triton } X-100\end{array}$ & 4.86 & 0.008 & 0.16 \\
\hline $\begin{array}{l}\text { II. Potter-Elvehjem homogenizing } 3 \text { freeze- } \\
\text { thaw cycles, sonification for } 3 \times 10 \\
\text { sec }\end{array}$ & 4.65 & 0.14 & 2.17 \\
\hline $\begin{array}{l}\text { III. Potter-Elvehjem homogenizing, } 3 \text { freeze- } \\
\text { thaw cycles }\end{array}$ & 3.98 & 0.58 & 14.6 \\
\hline $\begin{array}{l}\text { IV. Potter-Elvehjem homogenizing, } 1 \text { freeze- } \\
\text { thaw cycle }\end{array}$ & 3.07 & 0.85 & 27.7 \\
\hline V. Potter-Elvehjem homogenizing & 0.31 & 0.09 & 29.0 \\
\hline
\end{tabular}

Table 6. Inhibition of glutaryl-CoA dehydrogenase activity by $K C N$ and antimycin $A$ using both $M B$ and endogenous electron acceptors

\begin{tabular}{|c|c|c|c|}
\hline \multirow[b]{2}{*}{ Assay mixture } & \multicolumn{2}{|c|}{$\begin{array}{c}\text { Glutaryl-CoA dehydrogenase } \\
\text { activity } \\
(\mu \mathrm{mol} / \mathrm{h} / \mathrm{g} \text { protein })\end{array}$} & \multirow[b]{2}{*}{$\frac{100 \times B}{A}$} \\
\hline & $\begin{array}{c}\text { With } M B \text { as } \\
\text { EA (A) }\end{array}$ & $\begin{array}{c}\text { With endogenous } \\
\text { EA (B) }\end{array}$ & \\
\hline Normal & 2.01 & 0.32 & 15.9 \\
\hline$+10 \mathrm{mmol} /$ liter $\mathrm{KCN}$ & 0.76 & 0.02 & 2.6 \\
\hline $\begin{array}{l}+2 \mathrm{mg} / \text { liter antimy- } \\
\quad \operatorname{cin} \mathrm{A}\end{array}$ & 1.49 & 0.10 & 6.7 \\
\hline
\end{tabular}

Table 7. The activity of glutaryl-CoA dehydrogenase with both $M B$ and endogenous electron acceptors in a normal homozygote, GA I and GA II heterozygotes, and homozygotes

\begin{tabular}{|c|c|c|c|}
\hline \multirow[b]{2}{*}{ Fibroblast cell line } & \multicolumn{2}{|c|}{$\begin{array}{c}\text { Glutaryl-CoA dehydrogenase } \\
\text { activity } \\
(\mu \mathrm{mol} / \mathrm{h} / \mathrm{g} \text { protein })\end{array}$} & \multirow[b]{2}{*}{$\frac{100 \times B}{A}$} \\
\hline & $\begin{array}{l}\text { With } \mathrm{MB} \text { as } \\
\text { EA (A) }\end{array}$ & $\begin{array}{l}\text { With endogenous } \\
\text { EA (B) }\end{array}$ & \\
\hline Normal homozygote & 2.86 & 0.44 & 15.4 \\
\hline GA I heterozygote & 1.34 & 0.24 & 17.9 \\
\hline GA I homozygote & 0.00 & 0.00 & \\
\hline $\begin{array}{l}\text { GA II heterozygote, } \\
\text { mother }\end{array}$ & 1.96 & 0.37 & 18.9 \\
\hline $\begin{array}{l}\text { GA II hetrozygote, } \\
\text { father }\end{array}$ & 2.99 & 0.53 & 17.7 \\
\hline GA II homozygote & 2.68 & 0.014 & 0.5 \\
\hline
\end{tabular}

acyl-CoA dehydrogenases to be able to deliver electrons to $\mathrm{CoQ}_{10}$ and thereby to the main ETC. A defect in either one of these factors would abolish the in vivo activity for all the acyl-CoA dehydrogenases. A defective ETF common to all the deficient dehydrogenases has been suggested by several investigators including ourselves $(7,8)$. Recently, the ETF has been measured by Rhead et al. (12) in fibroblasts from the first reported patient with GA II and found to be normal or increased. He used a system with excess pig liver GADH, octanoyl-CoA as substrate and DCPIP as the terminal EA. This system requires an additional EA for transfer of electrons from GADH to DCPIP such as phenazine methosulfate or naturally occurring ETF. Rhead et al. (personal communication) used fibroblast mitochondrial sonicate as the ETF source and assumed the reduction in DCPIP to be a measure of the ETF activity. However, the fibroblast mitochondrial sonicate contains thiolases which hydrolyze octanoyl$\mathrm{CoA}$ and liberate thiol groups that are able to reduce DCPIP (12).

As ETF and ETF-DH activity seems difficult to measure in fibroblasts, we have tried to obtain an indirect measure of their combined activity by measuring GDH with intact ETS and without exogenous EA. GDH activity is then dependent on both a normal GDH, ETF, ETF-DH, and an intact ETC. GA II homozygotes have very low activity using this method whereas they have normal activity with $\mathrm{MB}$ as EA. These results strongly indicate a normal GDH apoenzyme but that one of the components in the electron transport chain from GDH to molecular oxygen is defective. As the oxidation of NADH and succinate seems to be normal in GA II, the ETC from $\mathrm{CoQ}_{10}$ to $\mathrm{O}_{2}$ is very likely also intact (13). The possible defect in GA II is then limited to ETF or ETF-DH.

Neonatal GA II has been suggested to be inherited as an Xlinked disease (3). The support for this has been that most of the patients found so far have been male infants. However, the case described by us who had the severe neonatal form of the disease was a female. This leads to different possibilities. The severe neonatal form can be a heterogenous group with more than one biochemical defect, one being X-linked and one autosomal recessively inherited. A way to distinguish between these possibilities would be to show half-normal activity in the GA II parents. As the exact defect in GA II is not known at present, this must be done indirectly. The oxidation of fatty acids in intact GA II fibroblasts is very much decreased (see Table 2 ). If intermediate oxidation rates of fatty acids could be shown in parents of GA II patients, this would strongly support a recessive inheritance. Our method that measures GDH with intact ETC as EA to diagnose 
GA II cannot distinguish the parents from normal individuals although the method measures half-normal activities in GA I parents (see Table 7). An explanation for this discrepancy could be that GDH is the limiting factor in this assay as indicated by the intermediate values in the obligate GA I heterozygotes. Halfnormal concentration of ETF or ETF-DH would then still be enough for full GDH activity. Another possibility is that the synthesis of the missing enzyme in GA II (i.e. ETF or ETF-DH) is regulated so the one gene that is functioning in GA II heterozygotes keeps working until a normal enzyme level is reached. This cannot occur in GA II homozygotes where both genes are defective.

Although the normal GDH activity measured with intact ETC as EA is a disadvantage in the diagnosis of GA II heterozygotes, it makes prenatal diagnosis of GA II homozygotes easier because of the high difference in enzyme activities between GA II heterozygotes and homozygotes.

\section{REFERENCES AND NOTES}

1. Christensen E. Brandt NJ 1978 Studies on glutaryl-CoA dehydrogenase in leucocytes, fibroblasts and amniotic fluid cells. The normal enzyme and the mutant form in patients with glutaric aciduria. Clin Chim Acta 88:267

2. Christensen $E 1983$ Improved assay of glutaryl-CoA dehydrogenase in cultured cells and liver: application to glutaric aciduria type I. Clin Chim Acta 129:91

3. Coude FX, Ogier H, Charpentier C, Thomassin G, Checoury A, AmedeeManesme O, Saudubray JM, Frezal J 1981 Neonatal glutaric aciduria type II: an X-linked recessive inherited disorder. Hum Genet 59:263

4. Dancis J, Hutzler J, Cox RP 1979 Familial hyperlysinemia: enzyme studies, diagnostic methods, comments on terminology. Am J Hum Genet 31:290

5. DeLuca C. Kaplan NO 1958 Flavin adenine dinucleotide synthesis in animal tissues. Biochim Biophys Acta 30:6

6. Fazekas AG, Sandor T 1973 Studies on the biosynthesis of flavin nucleotides from $2-{ }^{14} \mathrm{C}$-riboflavin by rat liver and kidney. Can J Biochem 51:772

7. Goodman SI, McCabe ERB, Fennessey PV, Mace JW 1980 Multiple acyl-CoA dehydrogenase deficiency (glutaric aciduria type II) with transient hypersarcosinemia and sarcosinuria: possible inherited deficiency of an electron cosinemia and sarcosinuria: possible inh
transfer flavoprotein. Pediatr Res 14:12

8. Gregersen N, Kølvraa S, Rasmussen K, Christensen E, Brandt NJ, Ebbesen F, Hansen FH 1980 Biochemical studies in a patient with defects in the metabolism of acyl-CoA and sarcosine: another possible case of glutaric aciduria type II. J Inher Metab Dis 3:67

9. Kølvraa S, Gregersen N, Christensen E, Hobolth N 1982 In vitro fibroblasts studies in a patient with $\mathrm{C}_{6}-\mathrm{C}_{10}$-dicarboxylic aciduria: evidence for a defect in general Acyl-CoA dehydrogenase. Clin Chim Acta 126:53

10. Lowry OH, Rosebrough NJ, Farr AL, Randall RJ 1951 Protein measurement with the Folin phenol reagent. J Biol Chem 193:265

11. Przyrembel H, Wendel U, Becker K, Bremer HJ, Bruinvis L, Ketting D, Wadman SK 1976 Glutaric aciduria type II: report on a previously undescribed metabolic disorder. Clin Chim Acta 66:227

12. Rhead W Mantagos S, Tanaka K 1980 Glutaric aciduria type Il: in vitro studies on substrate oxidation, acyl-CoA dehydrogenases and electrontransferring flavoprotein in cultured skin fibroblasts. Pediatr Res 14:1339

13. Saudubray JM, Coude FX. Demaugre F, Johnson C, Gibson KM, Nyhan WL 1982 Oxidation of fatty acids in cultured fibroblasts: a model system for the detection and study of defects in oxidation. Pediatr Res 16:877

14. Sweetman L Nyhan WL, Trauner DA, Merritt TA, Singh M 1980 Glutaric aciduria type II. J Pediatr 96:1020

15. This research was supported by the Danish Medical Research Council.

16. The authors acknowledge the expert technical assistance of Mrs. Eva Korup, Mrs. Vibeke Winter, and Mrs. Mette Houman Møller

17. Requests for reprints should be addressed to: Ernst Christensen, Department of Clinical Genetics. University of Copenhagen, Rigshospitalet 4062, Blegdamsvej 9, 2100 Copenhagen, Denmark.

18. Received for publication August 6,1983

19. Accepted for publication October 19,1983

\title{
Phototherapy for Neonatal Jaundice: in Vitro Comparison of Light Sources
}

\author{
JOHN F. ENNEVER, ${ }^{(20)}$ MARK SOBEL, ANTONY F. MCDONAGH, AND WILLIAM $\Upsilon$. SPECK \\ Department of Pediatrics, Rainbow Babies and Childrens Hospital, Case Western Reserve University School of \\ Medicine, Cleveland, Ohio USA [J.F.E., M.S., W.T.S.]; and Department of Medicine and Liver Center,
} University of California, San Francisco, California USA [A.F.M.]

\section{Summary}

Phototherapy results in the conversion of bilirubin to more water-soluble isomers. Six clinically used phototherapy lamps which differ in their emission spectra have been compared in their ability to produce configurational and structural isomers of bilirubin in vitro. For all of the lamps, the initial rate of configurational isomerization was highly correlated $(r=0.969)$ with the intensity of irradiation falling within the bilirubin absorption band. The percentage of the total bilirubin converted to the configurational isomer at equilibrium was dependent upon the spectral distribution of the lamp, and was greatest $(26.2 \pm 1.3 \%)$ with the special blue lamp, which has a narrow spectral output centered at $445 \mathrm{~nm}$. The rate of formation of the structural isomer, lumirubin, was generally dependent upon the intensity of irradiation within the bilirubin absorption band.

Abbreviation

HEPES, $N$-2-Hydroxyethylpiperazine- $N^{\prime}$-2-ethanesulfonic acid
Despite the widespread use of phototherapy for the prevention and treatment of neonatal jaundice, debate continues over the most effective light source $(2,6,15-19)$. Thus, several phototherapy units which differ in spectral distribution and intensity have been recommended. These recommendations are based on empirical studies which compared the effect of different light sources on serum bilirubin concentration in jaundiced infants $(15-19)$ or congenitally jaundiced Gunn rats (2). A limitation of such studies is that the measured effect of phototherapy, i.e. decline in serum bilirubin, is a secondary and delayed response $(3,10)$ (Ennever, Knox, Denne, and Speck, submitted). The primary effect of the treatment is rapid conversion of bilirubin to excretable photoproducts $(8,13,14)$ (Ennever et al., submitted). These include yellow compounds which are isomers of bilirubin (i.e. which have the same chemical formula) $(11,13)$. The decline in serum bilirubin requires transport of these photoisomers from their site of formation to the liver where they are excreted in the bile (14). Recent studies have shown that the rates of excretion of these photoproducts are different in the 